\title{
Evaluating the Revisionist Critique of Just War Theory
}

\author{
Seth Lazar
}

Abstract: Modern analytical just war theory starts with Michael Walzer's defense of key tenets of the laws of war in his Just and Unjust Wars. Walzer advocates noncombatant immunity, proportionality, and combatant equality: combatants in war must target only combatants; unintentional harms that they inflict on noncombatants must be proportionate to the military objective secured; and combatants who abide by these principles fight permissibly, regardless of their aims. In recent years, the revisionist school of just war theory, led by Jeff McMahan, has radically undermined Walzer's defense of these principles. This essay situates Walzer's and the revisionists' arguments, before illustrating the disturbing vision of the morality of war that results from revisionist premises. It concludes by showing how broadly Walzerian conclusions can be defended using more reliable foundations.

SETH LAZAR is a Senior Research Fellow at the Australian National University's School of Philosophy. He is the author of Sparing $\mathrm{C} i$ vilians (2015) and coeditor of The Morality of Defensive War (2014) and the Oxford Handbook of Ethics of War (2016). He has published in such journals as Ethics, Philosophy \& Public Affairs, and Australasian Journal of Philosophy.
Some dismiss the very idea of just war theory. Of those, some deny that morality applies in war; for others, morality always applies, everywhere, and it could never license the horrors of war. The first group are sometimes called realists, the second: pacifists. Just war theory seeks a middle path : to justify war, but also to limit it. Wherever there have been wars, lawyers, theologians, and philosophers have sought to walk this line. Though most commonly associated with the Christian tradition, different iterations of just war theory are part of every culture. ${ }^{1}$ In this essay, I will focus on contemporary just war theory in the works of Anglophone analytical philosophers: I'll call this analytical just war theory. And I will focus on the debate between the most prominent contemporary just war theorist, Michael Walzer, and his critics. Narrower still, I will focus on one question in that debate: how ought we to fight?

The "ought" in that question is unqualified. Our topic is neither the laws of war nor a side's rules of engagement. Our focus instead is on the categorical

(C) 2017 by the American Academy of Arts \& Sciences doi:10.1162/DAED_a_oo426 
Evaluating moral ought - the one that admits of no exthe Revisionist Critique of Just War Theory question, arguing that there are no moral truths, or that morality itself is conventional or culturally relative. But war is a tough arena for skeptics and relativists. Is there any question that it is wrong to intentionally kill children to coerce their government into political or territorial concessions? Though we cannot make much progress by focusing on such easy cases alone, we also cannot vindicate the deep moral revulsion that such scenarios inspire without acknowledging some objectivity in the morality of war.

So how do we argue about the morality of war? Most analytical just war theorists adopt Rawls's method of "reflective equilibrium."2 In this approach, we develop moral arguments by taking our considered judgments about the permissibility of actions in particular cases and trying to identify the underlying principles that unify them. ${ }^{3}$ We then take those principles and test how they apply to other cases, real or hypothetical. If the principles generate conclusions that conflict with our considered judgments about those cases, then we must revise either the principles or our judgments. As our project evolves, and we revise our principles in light of our judgments and our judgments in light of our principles, we approach reflective equilibrium (the underlying standard of epistemic justification is coherentist).

In this essay, I focus only on how we ought to fight, not on when. Narrower still, I focus on three candidate principles that purport to govern the conduct of hostilities. Noncombatant immunity states that intentionally killing noncombatants is impermissible. 4 The principle of proportionality dictates that the unintentional killing of noncombatants is permissible only if it is proportionate to the goals the attack is intended to achieve. And combatant equality applies these principles and others governing conduct in war identically to all combatants, regardless of what they are fighting for. These principles divide the possible victims of war into two classes: combatants and noncombatants. Combatants may be killed without restraint. ${ }^{5}$ But noncombatants may be killed only unintentionally, and even then, only if the harm that they suffer is proportionate to the intended goals of the attack. Obviously, then, knowing what makes one a combatant is crucial. For the purposes of this essay, I understand these categories as they are understood in international law. Combatants are members of the armed forces of a group that is at war and nonmembers who directly participate in hostilities. Noncombatants are not combatants. These are deceptively simple categories; hard cases abound. But the three principles on which I will focus raise challenging enough philosophical problems, even when considering only the clear-cut cases.

Noncombatant immunity, proportionality, and combatant equality each have deep philosophical roots. But they have been most clearly articulated and espoused in twentieth-century international law, specifically Additional Protocol I to the Geneva Conventions, 1977. For noncombatant immunity, see, for example, the "Basic Rule," Article 48, which states: "In order to ensure respect for and protection of the civilian population and civilian objects, the Parties to the conflict shall at all times distinguish between the civilian population and combatants and between civilian objects and military objectives and accordingly shall direct their operations only against military objectives." 6 For proportionality, see Article 51, which prohibits " an attack which may be expected to cause incidental loss of civilian life, injury to civilians, damage to civilian objects, or a combination thereof, which would be excessive in relation to the concrete and direct military advantage an- 
ticipated."7 For combatant equality, see Article 43 (among other sections), which defines who may be considered a combatant before explicitly stating that "combatants... have the right to participate directly in hostilities." 8 The preamble, meanwhile, makes clear that these principles apply "without any adverse distinction based on the nature or origin of the armed conflict or on the causes espoused by or attributed to the Parties to the conflict." 9 The contemporary just war debate began with an attempt to vindicate these legal and customary norms, in a book published the same year as the first additional protocol.

\section{$\mathrm{M}$} chael Walzer's Just and Unjust Wars was influential in numerous academic disciplines, as well as in public policy and military education; its uptake in analytical just war theory is only one dimension of that influence. Just and Unjust Wars takes on realists and pacifists, addresses questions of resort, conduct, and aftermath, and explores topics that have since been largely (and inexplicably) neglected, including the ethics of sieges, reprisals, and maintaining neutrality while other states make war. Noncombatant immunity, proportionality, and combatant equality are only part of his theory, but are at the heart of the "war convention" that Walzer sought to vindicate: "the set of articulated norms, customs, professional codes, legal precepts, religious and philosophical principles, and reciprocal arrangements that shape our judgements of military conduct."10

A single argument underpins noncombatant immunity and combatant equality and lays the foundations for proportionality. The basic idea is simple. Individual human beings enjoy fundamental rights to life and liberty, which prohibit others from using or harming them in certain ways. Fighting wars means depriving others of life and liberty, so it can be permissible only if each of the victims has "through some act of his own ... surrendered or lost his rights." ${ }^{11}$ Seth Walzer then claims that "simply by fight- Lazar ing," all combatants "have lost their title to life and liberty." 12 He makes two arguments. First: simply by posing a threat to me, a person alienates himself from me, and from our common humanity, and so himself becomes a legitimate target of lethal force. ${ }^{13}$ Second: by participating in the armed forces, a combatant has "allowed himself to be made into a dangerous man," and thus surrenders his rights. ${ }^{14}$ Besides combatants, "everyone else retains his rights." 15 Noncombatants are "men and women with rights, and ... they cannot be used for some military purpose, even if it is a legitimate purpose."16

Since noncombatants retain their rights, they are not legitimate objects of attack. This vindicates noncombatant immunity. Conversely, all combatants lose their rights, regardless of what they are fighting for; thus, if a force attacks only enemy combatants, they will fight legitimately, because they will not violate anyone's rights. This gives us combatant equality.

Proportionality requires a little more work. Walzer says that individual noncombatants have rights not to be used to advance military goals. But their rights do not protect them as fully against being harmed in the course of one side achieving its military objectives. His argument for proportionality is grounded in compromise: wars cannot be fought without unintentionally killing noncombatants; so if we resist pacifism, we must allow for some unintended killing of noncombatants, as long as it is proportionate to the intended objective. Indeed, besides merely being proportionate, an attack must also minimize risk to noncombatants, at least when weighed against the military objective and the additional risks placed upon the combatants themselves.

In Just and Unjust Wars, Walzer offers some supplementary arguments for these 
Evaluating core principles of just conduct in war. He the Revisionist Critique of Just War Theory

notes that combatants on both sides of most conflicts have very similar experiences. They tend to believe they are justified in fighting, and indeed fight for good reasons: loyalty, a belief that their country is under threat, and trust in their leaders, to name a few. ${ }^{17}$ Where these reasons are absent, combatants often fight under duress. In either case, they fight because they think they have to. When they share so many similar motivations, it would be hypocritical of either side's soldiers to blame the other side for fighting. Additionally, since from each soldier's perspective luck determines whether his war is just, we might think it unfair to make unjust combatants alone bear the results. ${ }^{18}$ In later works, Walzer also argues that the distinctly collective nature of participation in the military knits combatants together; regardless of what they do as individuals, the mere fact of their membership in a collective actively engaged in hostilities makes them liable to harm in a way that is not true for nonmembers. ${ }^{19}$

\section{$\mathrm{I}$} n Just and Unjust Wars, Walzer seeks both to interpret and to vindicate the war convention. It would therefore be misleading to reduce his contribution to a series of arguments that stand or fall on their merits. If those arguments fail, then his attempt to justify the war convention fails. But his interpretation of that convention might still ring true, such that we had better find some argument that vindicates it, lest our theory be radically out of step with common sense about war.

And yet, Walzer's arguments must be tested like any others. ${ }^{20}$ Analytical just war theorists have powerful objections to Walzer's positions on noncombatant immunity and combatant equality; proportionality is also controversial, though less so. The most influential proponent of the revisionist critique of Walzer has been the philosopher Jeff McMahan, but similar arguments have been advanced by others. ${ }^{21}$

The simplest and most telling objection against combatant equality brings it into conflict with proportionality. ${ }^{22}$ As unintended noncombatant deaths are permissible only if proportionate to the military objective sought, that means that the objective is worth some amount of innocent suffering. But what is a military objective worth? Daesh's capture of Raqqa or Mosul plausibly count as "military objectives." How many innocent deaths was achieving those goals worth? How many innocent deaths would be proportionate to the Lord's Resistance Army driving African Union forces out of South Sudan?

In each case, the answer is obvious: none. Proportionality is about weighing the evil inflicted against the evil averted. ${ }^{23}$ But the military success of unjust combatants does not avert evil; it is itself evil. Evil inflicted intentionally can only add to, not counterbalance, unintended evils. Thus, combatant equality cannot be true. All war involves unintended innocent deaths. If these deaths cannot be justified, then fighting is wrong. And if you advance only wrongful aims, then you achieve no good that can justify these deaths. The laws of war cannot be directly grounded in objective moral norms. ${ }^{24}$

The revisionists did not stop there. They developed further arguments against combatant equality, which also undermine noncombatant immunity. They first accept Walzer's premise that, in war, combatants may intentionally kill all and only those who have "surrendered or lost" their rights to life and liberty. These rights connect directly to our possession of moral status, indeed, might even be constitutive of it. We cannot surrender or lose these rights except by doing something that warrants such a severe fate. But Walzer's account of how these rights are lost is not plausible, they maintain. He argues that combatants lose their rights because they 
threaten the lives of others. Their dangerousness grounds their liability. But merely posing a threat to others - even a lethal threat - is not sufficient to warrant surrender of one's fundamental rights, because there can be very good reasons to threaten another's life.

Allied soldiers landing on the shores of Normandy during World War II were fighting against genocide and imperialist expansion; their adversaries were defending those iniquitous ends. ${ }^{25}$ Why should the Allies lose their rights, only by doing what they are clearly morally permitted, perhaps even required, to do? Why would the soldiers of the Peshmerga, fighting to rescue Yazidi Christians from genocidal attacks by Daesh, lose their rights not to be killed by their quasi-fascist adversaries? In no other sphere of human activity does posing a threat in pursuit of a just aim, a threat against those actively trying to thwart that just aim, vitiate one's rights against being harmed by those very people. Merely posing a threat to another's life cannot justify the loss of one's rights. Combatants fighting for just aims retain their rights to life and liberty. So combatant equality is false: just combatants are permitted to kill unjust combatants, but not vice versa.

Posing a threat oneself is not sufficient to become liable to be killed. Nor is it necessary. Revisionists argue that liability to be killed, in war as elsewhere, is grounded not in posing a threat, but in one's responsibility for a wrongful threat. As such, the U.S. president is responsible for a drone strike that he orders, even though he does not personally fire the weapon. Similarly, from his villa in Abbottabad, Bin Laden could not pose any threats himself. But he may have been responsible for many.

This argument undermines noncombatant immunity. ${ }^{26}$ Noncombatants play an important role in the resort to military force. In modern industrialized coun- tries, as much as 25 percent of the popu- Seth lation works in war-related industries. ${ }^{27}$ Lazar Further, we provide the belligerents with crucial financial and other services; we support and sustain the soldiers who do the fighting; we pay our taxes and in democracies we vote, providing the economic and political resources without which war would be impossible. Noncombatants' contributions to the state's capacity over time give it the strength and support to concentrate on war. If the state's war is unjust, then many noncombatants are responsible for contributing to wrongful threats. They are therefore permissible targets. So, by these lights, noncombatant immunity, too, is false. ${ }^{28}$

Most revisionists accept proportionality. But the same techniques used against combatant equality and noncombatant immunity place its application to war in doubt. First, note that the licence to unintentionally kill innocent people in war is far more permissive than would ever be plausible outside of war. Outside of war we almost never contemplate knowingly killing innocent people as a side effect of pursuing our legitimate objectives. ${ }^{29}$ What, then, explains the additional leeway granted in war?

Moreover, many philosophers think that the purported moral distinction between intended and unintended killing is illusory. ${ }^{30}$ Even supposing we set their worries aside, whose intentions matter in war? The one who pulls the trigger? Her immediate superior, who ordered the shot? The commander who ordered the attack? The politician who ordered the advance? Are intentions relevant if war-making is such a corporate effort?

Perhaps even these questions have answers. Still, Walzer's argument for proportionality is brief. If proportionality were not true, we could never fight justified wars. But why treat that as an argument for proportionality, rather than the first step toward 
Evaluating pacifism? We need some other argument the Revisionist Critique of Just War war impermissible!

Theory So, combatant equality is doubly false. Combatants who unintentionally kill noncombatants in the pursuit of unjust aims cannot satisfy proportionality. But their intentional killing is also wrongful, as long as they target combatants fighting for just aims, who retain their rights to life - in the relevant sense, those just combatants are innocent. Noncombatant immunity is false because noncombatants, like combatants, can be responsible for contributing to wrongful threats to others' lives, and so can themselves become liable to be killed. Proportionality is more widely endorsed, but many think it rests on a spurious distinction between intended and unintended killing, and that Walzer's argument for it begs the question against pacifism.

T hus far the revisionist critique of Walzer appears successful. So we have two options: argue that the war convention is mistaken, and combatant equality, noncombatant immunity, and proportionality are all false at the level of objective morality; or we can advance new arguments in support of those principles. I think that we should devote all our intellectual resources to the latter goal, accepting the former only if all else fails.

Combatant equality one can take or leave; it is already pragmatically justified by the fact that combatants will almost always believe that they are fighting for just aims, so any constraints applied to those fighting unjustly would simply be ignored. But giving up on noncombatant immunity and proportionality is giving up on a lot.

If we reject these two principles, then we could go one of two ways. We could argue that intentional and unintentional killing of noncombatants is no worse than killing combatants, or that killing combatants is no better than killing noncombatants. The first path leads to unrestrained warfare, the second to pacifism.

But can we really believe that it is wrong for the Peshmerga to fight against Daesh, defending Yazidis against genocide, just because they will inevitably kill some innocent people along the way? And can we really accept that when Daesh kills Yazidi noncombatants, their actions are no worse than when they kill the Peshmerga fighters? Can we endorse the reasoning behind arguments that there is no such thing as an "innocent civilian" in Gaza, because the Palestinians elected Hamas ? ${ }^{31}$ Or the terrorists' parallel arguments for the permissibility of targeting citizens of Western countries because they are responsible for their governments' foreign policies ? ${ }^{2}$ These costs are too great to bear. We cannot simply accede to aggression. And we must not fight without restraint.

In what remains of this essay, I cannot vindicate the war convention. But I can sketch the most promising direction of travel.

$\mathrm{W}_{\mathrm{e}}$ e start with what should be a truism. Every person's innocent happiness makes the world a better place. More generally, our flourishing contributes value to the universe. And we always have some reason to make the world a better place. But that is not all we have reason to do. To see this, let us briefly contrast moral value with economic value.

Imagine you are a manufacturer. Your factory has a number of different machines on your assembly line. Each contributes to your overall productivity, and each generates expenses. You care about each machine only insofar as it affects your profits. If one becomes a net cost, then you will shut it off without compunction. If you can realize more profit by taking one machine apart, and using it as spares for another, then you will do so. 
If ethics were like business, then we would maximize value like profits, and treat people like machines. We would harm one person just in case doing so would deliver a marginally greater benefit to another. This treats her as a mere site of value, because her weight in our deliberations is exhausted by the value that is instantiated in her life. Following this logic, we would even, for example, harvest an unwilling victim's organs to save the lives of others. This treats him as a tool for realizing value, broken down for spare parts like a machine. ${ }^{33}$

Ethics is not like business. People are not mere sites or tools for the realization of value. Recognizing this amounts to recognizing that people have moral status. Why do we have moral status? Explaining this is no easy task. I think it is grounded in our rational capacity to make our own choices, for our own reasons. But even if we disagree about what grounds moral status, we can agree on its normative implications. And, like Walzer, we can most fruitfully understand those in terms of individual rights.

Our fundamental human rights to life and liberty protect us against being treated as mere sites or tools for the realization of value. To sacrifice my interests for the greater good, or to use me as a means to advance the greater good, is not merely to harm me (subtracting that much value from the world) but to infringe my rights. That your action infringes my rights constitutes an additional reason against harming me, over and above the disvalue realized by doing so. This means you cannot justify harming me, just in case you could thereby do marginally more good. This is the difference between people and machines: machines do not have rights, so the executive can shut them down or use them for spare parts to maximize profits.

We can understand these rights in different ways. I want to insist only on three points. First, our fundamental rights should have neither trivial nor absolute weight. Seth They are not mere tie-breakers. But nor Lazar must we respect them though the heavens should fall. Their weight should be between those two extremes.

Second, the weight of a right can vary depending on how it is infringed. It is harder to justify infringing people's rights as a means to advance your goals than to justify harming them incidentally in the course of pursuing your goals. In the former case, you use the victim as a tool, like the executive breaking up the machine for parts. In the latter case, you are no better off for the victim's presence than you would have been had he not been there. His death (for example) is a regrettable, but unavoidable, side effect of achieving your goals. In this case, you treat him as a mere site for the realization of value. Just as it is worse to use someone than to harm him incidentally when you are aiming at the good, the same is true when aiming at the bad. All the killing done by Daesh fighters is deeply morally odious. But publicly beheading a victim to coerce his government is worse than, for example, killing a passerby in the blast when an improvised explosive device is triggered by an enemy vehicle.

Third, even one's most fundamental rights can be lost. Most analytical just war theorists agree that if you are sufficiently responsible for an unjustified threat that is serious enough to make killing proportionate, and if killing you is necessary, then you can be liable to be killed: that is, you "lose or surrender" your right not to be killed. In such cases, sacrificing you or using you as a tool to advance the good of others can be permissible.

One can be responsible for a threat in virtue of posing it oneself, or contributing to it, or even failing to prevent it. So liability can potentially extend not only to the soldier who pulls the trigger, but to the commander who orders him to do so, and to the politicians who give the command- 
Evaluating ers their orders, and perhaps even to the the Revisionist Critique of Just War

Unlike some other analytical just war
theorists, however, I think that for you citizens who elect the politicians. to be liable to be killed, you have to have done, or failed to do, something significant-something to which the loss of your fundamental rights is an appropriate response. Perhaps your causal contribution was itself significant (for example, the threat would not have occurred without your order). Or perhaps you are blameworthy for contributing as you did.

The he result: not all killings are equally seriously wrong. This is essential to any attempt to walk the line between realism and pacifism. When killing for just aims, killing those with rights is worse than killing those who have lost them; killing people as a means is worse than killing them as a side effect. When killing for unjust aims, all the killing one does is wrong, but still, some wrongful killing is worse than others.

But how do these categories map onto the combatant/noncombatant divide so essential to the war convention? Imperfectly, we must admit. Walzer was right that almost all noncombatants retain their rights to life. Here I disagree with the revisionists, who think that one can be liable by virtue of minimal responsibility for a wrongful threat. ${ }^{34}$ If that were right, then all the noncombatants whose voluntary actions foreseeably contribute to their state's capacity to wage unjust wars would be liable to be killed. Few adults would escape liability on these grounds.

This is not the place for a detailed investigation into responsibility and liability. But nor is one necessary. I doubt whether any theoretical account, or any intuitions about hypothetical cases, could be as robust as my intuitions about the actual case of war. Ordinary voters and taxpayers are not liable to be killed, even when their militaries foreseeably fight unjust wars. Kill- ing them intentionally does wrong them - egregiously. For example, British and American citizens who voted for the governments that fought an unjust war in Iraq in 2003, and paid the taxes that funded that war, were not liable to be killed in order to avert the unjust threats that the war involved.

The best theoretical explanation for this judgment is the one alluded to above: that there must be some fit between one's behavior and the fate of becoming liable to be killed. But once we concede that point, then we must also concede that for many combatants in war, even those fighting for the unjust side, this fit is absent. 35 This is obviously true of combatants on the just side - those fighting for just aims do nothing to lose or surrender their rights. But against both Walzer and the revisionists, it is true also for many combatants on the unjust side. Many of them neither pose threats themselves, nor contribute to threats posed by their comrades. Many make no difference at all; some are a positive hindrance. As Walzer notes, many serve for good reasons - out of loyalty and a belief that their cause is just. A grisly death no more fits their behavior than it does that of many noncombatants. What's more, in all conflicts this clean division between the "just side" and the "unjust side" falls apart. Many combatants fighting for the ostensibly just side contribute to subsidiary unjust aims and operations and so lose their rights to life; many fighting for the ostensibly unjust side contribute to subsidiary just aims and operations, and so retain those rights.

If almost all noncombatants retain their rights to life in war, then many combatants, even on the unjust side, will keep the same rights. So, to deny pacifism, we must reject Walzer's dictum that legitimate acts of war respect the rights of those against whom they are directed. In passing, this makes perfect sense. The contrary idea is 
one of a "morally pure" war, in which nobody's rights are intentionally violated. Such an ideal is unattainable in the real world. If just wars could be fought by intentionally killing only those who are liable to be killed, then wars would not be such tragic affairs.

So, noncombatants may not be intentionally attacked, because they retain their rights to life. My basis for noncombatant immunity is therefore the same as Walzer's. Killing them unintentionally can be permissible even when intentional killing is not, because we enjoy stronger protections against being harmed as a means, than against being harmed incidentally in the course of achieving some end. Walzer's pragmatic argument for proportionality is unnecessary: this distinction (or something close to it) is central to plausible theories of normative ethics.

Combatant equality is trickier. Noncombatant immunity applies to soldiers on both sides. But proportionality does not apply in quite the same way, since it gives a necessary condition for unintentional killing to be permissible. But unjust combatants cannot kill permissibly in the pursuit of unjust aims, whether unintentionally or otherwise. Still, the basic distinction that proportionality describes applies to unjust combatants as well, and if they are going to fight, they had better kill noncombatants unintentionally than kill them as a means. So something close to combatant equality is true: just combatants should respect the rules of war because only by doing so can they fight justly; unjust combatants should respect those rules because they thereby minimize the wrongfulness of their actions. ${ }^{36}$

However, there is still more work to do. As argued above, many combatants, even on the unjust side, retain their rights not to be killed. So if my justification for noncombatant immunity is not to entail pacifism, we must explain how attacking nonliable combatants can be permissible, with- out thereby justifying attacks on nonliable Seth noncombatants. We need to show that kill- Lazar ing innocent noncombatants is worse than killing innocent combatants. I defend this principle at length elsewhere. ${ }^{37}$ Here I will just allude to three arguments in its favor.

First, the fact that noncombatants are so much likelier than combatants to retain their rights to life itself makes killing innocent noncombatants worse than killing innocent combatants, because it is, other things equal, worse to kill someone more riskily than less riskily. Intentionally killing civilians amounts to taking a very great risk of killing an innocent person; intentionally killing combatants takes a lesser risk. Riskier killings are worse than less risky ones, because they display a greater readiness to treat one's target as a site or tool for the realization of one's ends, and because they more seriously undermine our interest in security.

Second, noncombatants are more vulnerable and defenseless than are combatants. They are likelier to suffer more severe harm from any given threat that they face; and they are less able to remediate the risks imposed on them. We have basic duties to protect those who are most vulnerable (as long as they are not liable to suffer some harm), and attacking the vulnerable not only violates their ordinary rights to life and liberty, but breaches these additional duties of care. Additionally, when we attack the defenseless, we deprive them of control over some of their most important interests. We render them dependent on us or on their defenders. This additional harm compounds the wrongfulness of killing them: whenever you kill a defenseless person, you have not merely killed him or her, but disempowered him or her as well.

Third, even combatants who pose only justified threats typically enjoy weaker protections against intentional harm than do noncombatants, even though neither are liable to be killed. This is because most 
Evaluating combatants have no control over whether the Revisionist Critique of Just War Theory identical, but they would have been killing unjustly. So, though they are not liable to be killed, because they contribute only to just threats, this is a matter of luck. We owe more to those who respect our rights robustly (such as noncombatants who do not pose threats) than to those who respect our rights only through luck.

These are just sketches of the necessary direction of travel. The strategy is to show that even though Walzer was wrong to think that only noncombatants retain their rights to life in war, his revisionist critics are wrong to think that just com- batants enjoy undiminished moral protections against harm, and that all unjust combatants are liable to be killed. Matters are much messier than either side supposed. The real challenge is not to explain why noncombatants are immune from intentional attack in war, that part is relatively easy: they retain their rights to life. Instead, it is to explain why killing unjust combatants is permissible, given that many of them also are not liable to be killed. The task is less one of explaining noncombatant immunity, but of explaining combatant nonimmunity. If we cannot do this, then there may ultimately be no stopping point short of endorsing pacifism.

\section{ENDNOTES}

Author's Note: Particular thanks to Nancy Sherman, Steve Woodside, and Scott Sagan for their comments on this essay.

${ }^{1}$ For comprehensive historical sources, see Gregory M. Reichberg, Henrik Syse, and Endre Begby, The Ethics of War: Classic and Contemporary Readings (Oxford: Blackwell, 2006).

${ }^{2}$ John Rawls, A Theory of Justice (Oxford: Oxford University Press, 1999), 42 - 45.

3 As I understand reflective equilibrium, each of us needs to make use of our own judgments about cases, rather than conduct surveys. Of course, if your considered judgments are radically out of step with everyone else's, then that gives you some reason to revise them.

${ }^{4}$ For simplicity throughout, I focus on killing, but everything I say applies to other harms as well.

${ }^{5}$ Other principles prohibit harming combatants in particular ways ; for example, with poisonous gas.

${ }^{6}$ International Committee of the Red Cross, Article 48, "Basic Rule," Protocol Additional to the Geneva Conventions of 12 August 1949, and Relating to the Protection of Victims of International Armed Conflicts (Protocol I), 8 June 1977, hosted at the International Committee of the Red Cross, https://ihl-databases .icrc.org/applic/ihl/ihl.nsf/Article.xsp?action=openDocument\&documentId=8A9E7E14C63C7 F30C12563CD0051DC5C. This basic principle is reiterated in various pieces of international law.

7 International Committee of the Red Cross, Article 51, "Protection of the Civilian Population," Protocol Additional to the Geneva Conventions of 12 August 1949, and Relating to the Protection of Victims of International Armed Conflicts (Protocol I), 8June 1977, hosted at the International Committee of the Red Cross, https ://ihl-databases.icrc.org/applic/ihl/ihl.nsf/Article.xsp?action=openDocument\& documentId=4BEBD9920AEOAEAEC12563CDOO51DC9E.

${ }^{8}$ International Committee of the Red Cross, Article 43, "Armed Forces," Protocol Additional to the Geneva Conventions of 12 August 1949, and Relating to the Protection of Victims of International Armed Conflicts (Protocol I), 8 June 1977, hosted at the International Committee of the Red Cross, https :// ihl-databases.icrc.org/applic/ihl/ihl.nsf/Article.xsp? action=openDocument\&documentId= AF64638EB5530E58C12563CDo051DB93.

9 International Committee of the Red Cross, "Preamble," Protocol Additional to the Geneva Conventions of 12 August 1949, and Relating to the Protection of Victims of International Armed Conflicts (Protocol I), 8 
June 1977, hosted at the International Committee of the Red Cross, https ://ihl-databases.icrc.org/ Seth applic/ihl/ihl.nsf/7c4do8d9b287a42141256739003e636b/f6c8b9fee14a77fdc125641eoo52bo79?. Lazar

10 Michael Walzer, Just and Unjust Wars: A Moral Argument with Historical Illustrations (New York: Basic Books, 2006), 44.

${ }^{11}$ Ibid., 135.

12 Ibid., 136.

13 Ibid., 142.

14 Ibid., 145.

15 Ibid., 136.

${ }^{16}$ Ibid., 137. Controversially, Walzer thought that noncombatant immunity could not be absolute: in "supreme emergencies" it might be permissible to intentionally attack noncombatants. See ibid., 251ff.

17 Ibid., 127.

18 Seth Lazar, "Responsibility, Risk, and Killing in Self-Defense," Ethics 119 (4) (2009): 699 - 728.

19 Michael Walzer, “Terrorism and Just War,” Philosophia 34 (1) (2006):3-12.

${ }^{20}$ By this I mean : verify whether the underlying principles have tenable implications when extended to other actual and hypothetical cases besides those Walzer considers.

${ }^{21}$ Jeff McMahan, "Innocence, Self-Defense and Killing in War," Journal of Political Philosophy 2 (3) (1994): 193-221; and Jeff McMahan, Killing in War (Oxford: Oxford University Press, 2009).

${ }^{22}$ McMahan, "Innocence, Self-Defense and Killing in War."

${ }^{23}$ Steven Lee, Ethics and War: An Introduction (New York: Cambridge University Press, 2012).

24 They might still be indirectly grounded, since these rules, for example, minimize wrongful killing overall. See Janina Dill and Henry Shue, "Limiting the Killing in War : Military Necessity and the St. Petersburg Assumption," Ethics \& International Affairs 26 (3) (2012): $311-333$.

25 They also had other reasons to fight : for example, to defend their comrades-in-arms. I discuss such reasons in Seth Lazar, "Associative Duties and the Ethics of Killing in War," Journal of Practical Ethics 1 (1) (2013): 3- 48.

${ }^{26}$ McMahan, "Innocence, Self-Defense and Killing in War"; and Helen Frowe, Defensive Killing (Oxford: Oxford University Press, 2014).

27 Alexander Downes, "Desperate Times, Desperate Measures: The Causes of Civilian Victimization in War," International Security 30 (4) (2006): 152 - 195, 157-158. See also Michael Gross, Moral Dilemmas of Modern War: Torture, Assassination and Blackmail in an Age of Asymmetric Conflict (Cambridge: Cambridge University Press, 2010), 159; and Benjamin Valentino, Paul Huth, and Sarah Croco, "Bear Any Burden? How Democracies Minimize the Costs of War," The Journal of Politics 72 (2) (2010): 351, $528-544$.

${ }^{28}$ Some think that noncombatants' responsibilities are especially salient in asymmetric conflicts, in which they are often crucial to the combatants' ability to fight. See, for example, Gross, Moral Dilemmas of Modern War.

29 We often permit practices that will predictably lead to accidents, but that's different from knowingly inflicting such casualties. Mass vaccination programs might be another example, though in those we run risks, rather than knowingly killing innocent people; the number risked is almost always very small relative to those benefited; and vaccinations are in the ex ante interest of all those who receive them, even those who end up, expost, being harmed. Thanks again to Scott Sagan here.

30 See, for example, Kai Draper, War and Individual Rights: The Foundations of Just War Theory (New York: Oxford University Press, 2016). 
Evaluating the Revisionist

Critique of Just War Theory

${ }^{31}$ Giora Eiland, "In Gaza, There Is NoSuch Thing as 'Innocent Civilians,, 'Ynetnews.com, May 8, 2014, http://www.ynetnews.com/articles/o,7340,L-4554583,00.html.

32 Osama Bin Laden, "Letter to America,” The Guardian, November 24, 2002, http://www.theguardian .com/world/2002/nov/24/theobserver.

33 The central idea here is obviously Kantian, but it finds its clearest modern expression in Warren S. Quinn, "Actions, Intentions, and Consequences: The Doctrine of Doing and Allowing," Philosophical Review 89 (1989): 287-312.

34 McMahan, Killing in War.

35 I argue for this point at length in Seth Lazar, "The Responsibility Dilemma for Killing in War: A Review Essay," Philosophy \& Public Affairs 38 (2) (2010): $180-213$.

36 For a detailed development of this idea, see Adil Ahmad Haque, Law and Morality at War (Oxford: Oxford University Press, forthcoming).

37 Seth Lazar, Sparing Civilians (Oxford: Oxford University Press, 2015). 